\title{
Identification of Sequence Changes in the Cold-Adapted, Live Attenuated Influenza Vaccine Strain, A/Ann Arbor/6/60 (H2N2)
}

\author{
NANCY J. COX, ${ }^{*, 1}$ FUMIO KITAME,, ALAN P. KENDAL, ${ }^{*}$ HUNEIN F. MAASSAB, $\neq$ AND CLAYTON NAEVE§ \\ *Influenza Branch, Division of Viral Diseases, Center for Infectious Diseases, Centers for Disease Control, Atlanta, Georgia 30333, +Department \\ of Bacteriology, Yamagata University, School of Medicine, Zao-lida, Yamagata 990-23, Japan, ₹Department of Epidemiology, School of Public \\ Health, The University of Michigan, Ann Arbor, Michigan 48104, §Department of Virology, \\ St. Jude Children's Hospital for Research, 322 N. Lauderdale, Memphis, TN 38101
}

Received February 29, 1988; accepted August 31, 1988

\begin{abstract}
Nucleotide sequences have been obtained for RNA segments encoding the PB2, PB1, PA, NP, M1, M2, NS1, and NS2 proteins of the influenza A/Ann Arbor/6/60 (H2N2) wild-type (wt) virus and its cold-adapted (ca) derivative that has been used for preparing investigational live attenuated vaccines. Twenty-four nucleotide differences between the $\mathrm{ca}$ and wt viruses were detected, of which 11 were deduced to code for amino acid substitutions in the ca virus proteins. One amino acid substitution each was predicted for the PB2, M2, and NS1 proteins. Two amino acid substitutions were predicted for the NP and the PA proteins. Four substitutions were predicted for the PB1 protein. The biological significance of mutations in the PB2, PB1, PA, and M2 genes of the ca virus is suggested by currently available genetic data, a comparison with other available influenza gene sequences, and the nature of the predicted amino acid changes. In addition, the sequence data confirm the close evolutionary relationship between the genomes of influenza A (H2N2) and influenza A (H3N2) viruses. 1988 Academic Press, Inc.
\end{abstract}

\section{INTRODUCTION}

One approach for producing live attenuated influenza A vaccines is attenuation of new epidemic variants by reassortment with a cold-adapted (ca) temperature-sensitive (ts) mutant donor strain, A/Ann Arbor/6/ 60 (H2N2) (Maassab et al., 1972; Kendal et al., 1981; Cox, 1986). This prototype ca virus was derived by serial passage of the wild-type (wt) A/Ann Arbor/6/60 virus at successively lower temperatures until virus emerged that could replicate efficiently at $25^{\circ}$ (Maassab, 1967; Kendal et al., 1981). Although the ca AVAnn Arbor/6/60 donor virus has not been thoroughly tested in human volunteers, it is attenuated in a ferret model system (Maassab et al., 1982). Reassortant viruses that received the hemagglutinin $(\mathrm{HA})$ and neuraminidase (NA) genes from a new $\mathrm{H} 1 \mathrm{~N} 1$ or $\mathrm{H} 3 \mathrm{~N} 2$ epidemic variant virus and five or six of their other genes from the ca AVAnn Arbor/6/60 parent have been examined extensively. These ca reassortants had similar ca and ts properties in cell culture, and were attenuated, immunogenic, and phenotypically stable when administered to ferrets (Maassab et al., 1982). They also were attenuated, immunogenic, and protective in challenge and field studies in humans (Davenport et al., 1977; Hrabar et al., 1977; Murphy et al., 1979, 1980, 1981, 1982; Lazar et al., 1980; Reeve et al., 1980b; Mortiz et al., 1980; Van Voorthuizen et al., 1981; Cate and

\footnotetext{
'To whom requests for reprints should be addressed.
}

Couch, 1982; Wright et al., 1982; Clements et al., 1983; Belshe and Van Voris, 1984; Couch et al., 1986).

It has not yet been determined if live ca viruses provide the theoretical benefits proposed for attenuated influenza vaccine (Stuart-Harris, 1980) or can be applied for influenza control on a large scale. Promising vaccine trials, however, have justified parallel laboratory studies to examine the molecular basis for attenuation and the genetic stability of the ca A/Ann Arbor/6/ 60 mutant. It was proposed previously that the restricted gene composition of ca reassortant viruses was advantageous for producing live attenuated influenza vaccines because viruses with five or six internal genes of the ca donor strain would be expected to have more uniform biological and attenuation properties (Cox et al., 1979). Genetic stability of several vaccine strains having five or six genes from the ca parent was examined before and after replication in humans using $\mathrm{T} 1$ oligonucleotide mapping, and relative genetic stability was demonstrated (Cox and Kendal, 1984). To directly identify genes of the ca donor strain A Ann Arbor/ $6 / 60$ that contained mutations, we used a variety of biochemical techniques to compare RNAs and proteins of the ca and wt viruses. These procedures detected differences in each of the eight RNA segments of the ca mutant compared with the wt parent (Cox et al., 1986). Here we present the entire nucleotide sequences for the six genes of the wt and ca AVAnn Arbor/6/60 viruses that are relevant for producing reas- 
sortant candidate vaccine viruses. Knowledge of these nucleotide sequences will be useful for monitoring genetic stability of attenuated vaccines during production and use as well as for understanding the molecular mechanism(s) of viral attenuation.

\section{MATERIALS AND METHODS}

\section{Viruses and viral RNA}

The AAnn Arbor/6/60 wt virus and the derivation of the ca A/Ann Arbor/6/60 mutant have been described (Maassab, 1967; Kendal et al., 1981). No further plaque purifications or end-point dilutions were performed. Viruses were propagated at a low multiplicity of infection in the allantoic cavity of 10-day-old embryonated eggs at $34^{\circ}$ and purified as described previously (Cox and Kendal, 1984). Ca mutant and wt virus preparations used throughout this study for sequencing varied by no more than three egg passages for the mutant $\left(E_{4}\right.$ to $\left.E_{6}\right)$ and by five egg passages for the wt $\left(E_{28}\right.$ to $\left.E_{32}\right)$. Sequencing of RNA obtained from these different passage levels of the same virus revealed no sequence differences. Virion RNA was extracted as described previously (Palese and Schulman, 1976) and dissolved to yield approximately $1 \mathrm{mg} / \mathrm{ml}$.

\section{Nucleotide sequence analysis of viral RNA}

Sequence analysis was accomplished using either of two variations of the dideoxy chain termination method (Sanger et al., 1977). The incorporative method was performed essentially as described previously (Air, 1979; Cox et al., 1986). Each 5.5- $\mu$ reaction mixture contained $45 \mathrm{mM}$ of Tris- $\mathrm{HCl}(\mathrm{pH} 8.3), 45$ $\mathrm{mM}$ of $\mathrm{KCl}, 4.5 \mathrm{mM}$ of $\mathrm{MgCl}_{2}, 9 \mathrm{mM}$ of DTT, $1.4 \mu \mathrm{M}$ of dATP, $12.5 \mu \mathrm{Ci}$ of $\left[\alpha^{3}{ }^{32} \mathrm{P}\right]$-dATP (NEN Research Products, Boston, MA), ${ }^{2} 45.5 \mu M$ of dGTP $(9.1 \mu M$ of dGTP for the G reaction), $4.5 \mu \mathrm{M}$ of dCTP $(9.1 \mu \mathrm{M}$ of dCTP for the $\mathrm{C}$ reaction), $45.5 \mu \mathrm{M}$ of dTTP $(9.1 \mu \mathrm{M}$ of dTTP for the Treaction), $50-100 \mathrm{ng}$ of RNA, 1-5 ng of primer, 3 units of reverse transcriptase (Life Sciences, Inc., St. Petersburg, FL), and 1-5 $\mu M$ of ddATP, ddCTP, ddGTP, or ddTTP. Reaction mixtures were incubated at $37^{\circ}$ for $30 \mathrm{~min}$, after which $1 \mu \mathrm{l}$ of a chase mixture containing $1 \mathrm{mM}$ each of dATP, dCTP, dGTP, and dTTP was added, and the incubation was continued at $37^{\circ}$ for $30 \mathrm{~min}$. Terminal deoxynucleotidyl transferase (Bethesda Research Laboratories, Gaithersburg, MD) was added to the chase mixture when necessary to resolve sequence abiguities (DeBorde et al., 1986).

\footnotetext{
${ }^{2}$ Use of trade names and commercial sources is for identification only and does not imply endorsement by the U.S. Public Health Service or the Department of Health and Human Services.
}

The reaction was stopped by adding $1 \mu \mathrm{l}$ of $0.1 \mathrm{M}$ EDTA, and samples were dried and finally dissolved in $5 \mu$ l of a formamide dye mixture.

The second method used $5^{\prime}-\gamma^{-32} P$-labeled synthetic oligodeoxynucleotides for priming the reaction. Each $5-\mu$ l reaction mixture contained $50 \mathrm{mM}$ of Tris $-\mathrm{HCl}(\mathrm{pH}$ 8.3), $50 \mathrm{mM}$ of KCl, $5 \mathrm{mM}$ of $\mathrm{MgCl}_{2}, 10 \mathrm{mM}$ of DTT, 50 $\mathrm{mM}$ each of dATP, dCTP, dGTP, and dTTP, 3.75 units of human placenta RNase inhibitor (Promega Biotec, Madison, WI), $200 \mathrm{ng}$ of RNA, 1-5 ng primer, 3 units of reverse transcriptase, and approximately $10 \mu \mathrm{M}$ of ddATP, ddCTP, ddGTP, or ddTTP. After incubation at $42^{\circ}$ for $30 \mathrm{~min}$, reaction products were analyzed on 6 and $8 \%$ polyacrylamide gels containing $100 \mathrm{mM}$ of Tris-borate (pH 8.3), $5 \mathrm{mM}$ of EDTA, and 8.3 $\mathrm{M}$ of urea.

Oligonucleotide primers were synthesized either by C. W. Naeve (St. Jude Children's Hospital) or by B. Holloway (Centers for Disease Control) on an Applied Biosystems Model 380A DNA synthesizer using the solidphase phosphoramidite method. Primers used were as follows: the universal primer d(AGCAAAAGCAGG), PB2-28 d(ATGGAAAGAATAAAA), PB2-102 d(GGACCATATGGC), PB2-225 d(GACAAGAGGATA), PB2-451 d(CGCCGAAGAGTT), PB2-698 d(CAAGCAGTGTAT), PB2-905 d(GGATGGTGGACA) PB2-946 d(GCTGTGGAAATATGC), PB2-1125 d(TGGGAAAAGGGC), PB21349 d(ATGCTAAAGTGC), PB2-1570 d(CCTGAGGAGGTC), PB2-1780 d(CCTAAGGCCATT), PB2-2085 d(GGAGTCAGCTGT), PB2-2190 d(GGCTAATGTACT), PB1-13 d(CAAACCATTTGAATGG), PB1-208 d(GGAGCGCCCCAACT), PB1-400 d(CGTCAGACCTATGA), PB1-601 d(GACAACATGACCAAGA), PB1-745 d(AATGCAACACCCGGGA), PB1-909 d(CACAGAGCTTTC), PB1-1000 d(ACAAGAAATCAACCT), PB1-1105 d(AGCATGAAGCTCCGAA), PB1-1375 d(GTGAATGCACCA), PB1-1600 d(GGAGTAACAGTG) PB1-1801 d(GATGGAGGACCAAACT), PB1-2046 d(CCTCAACACAAG), PB1-2209 d(GACTTCGAGTCTGGA), PA-158 d(GCTTCATGTATT), PA-226 d(CCAAATGCACTT), PA-452 d(CACACATCCACA), PA-681 d(CCCGCCGAACTT), PA-876 d(GATGGATGCTTT), PA-1112 d(CGAGTCAGCTAA), PA-1339 d(GCAAGCATGAGA), PA-1540 d(AAAGGAAGATCTCA), PA-1601 d(CTCTCACTGACC), PA-1789 d(CTCCAACAAATC), PA-1800 d(CGAGAGTATGAT), PA-1900 d(AAAGGAGTGGAAGAA), PA-2009 d(CAAGAAAACTGC), PA-2026 d(GTCGTTCAGGCT), PA-2080 d(CTATATGAAGCAATT), NP-160 d(TTCTACATCCAA), NP-202 d(GAGGGGCGACUG), NP-397 d(CGAATCTGGCGC), NP-643 d(GGGATCAATGAT), NP-888 d(TGGACCTGCCGT), NP-1015 d(CACAAGAGTCAG), NP-1285 d(GTGCAAAGAAACCTTC), M-239 d(CGAGGACTGCAG), M-438 d(GCTGACTCCCAG), M-719 d(GATCTTCTTGAAAATTTG), M-895 d(GAGGGCCTTCTA), NS-207 d(G- 
GAAAGCAGATAGTG), NS-384 d(GACCAGGCAATC), NS-597 d(ACAGTTCGAGTC) and NS-742 d(GAAGTGAGACAC). Primer numbers correspond to the position (in the mRNA sense sequence) of the first nucleotide in the primer.

\section{Nucleotide sequence analysis of mRNA}

The nucleotide sequence of the first 25-40 nucleotides of the $3^{\prime}$ region of each gene was obtained using synthetic primers complementary to viral mRNA. Confluent MDCK cells were infected at a multiplicity of approximately 2 PFU/cell and harvested by scraping at 6 or $8 \mathrm{hr}$ postinfection for the wt and mutant viruses, respectively. Cells were washed once in ice-cold phosphate-buffered saline and lysed in a buffer containing $5.8 \mathrm{M}$ of guanidinium-hydrochloride, $50 \mathrm{mM}$ of Tris$\mathrm{HCl}(\mathrm{pH} 7.6), 10 \mathrm{mM}$ of EDTA, $2 \%$ sodium lauryl sarkosinate, and $1 \% \beta$-mercaptoethanol prepared as described previously (Maniatis et al., 1982). RNA isolated by centrifugation through a $\mathrm{CsCl}$ cushion (Maniatis et al., 1982) was suspended in $20 \mathrm{mM}$ Tris $-\mathrm{HCl}(\mathrm{pH}$ 7.4), $1 \mathrm{mM}$ EDTA and $0.1 \%$ sodium dodecyl sulfate (SDS), ethanol precipitated, and stored at $-70^{\circ}$ in sterile distilled water. Approximately $50 \mu \mathrm{g}$ of total RNA was used in each incorporative sequencing reaction carried out as described above. Primers used were as follows: mNS-771 d(ATGGGGCATCACCTAGTT), mM-911 d(ACATCTTCAAGTCTCTGT), mNP-1433 d(CGACGGATGCTCTGATT), mPA-2151 d(GCTTITCAGCAAGCTCGACAATC), mPB1-2233 d(GAGGATCTCCAGTATAAG), and mPB2-2253 d(GTTAGTATCTCGCGAGTG). Primer numbers correspond to the position (in the virion sense RNA sequence) of the first nucleotide in the primer.

\section{Computer analysis}

Nucleotide sequences were stored and manipulated on a Digital Equipment Corp. VAX computer using version 5 of the sequence analysis software package of the University of Wisconsin Genetics Computer Group (Devereaux et al., 1984).

\section{RESULTS}

Nucleotide sequences of the NS1, NS2, M1, M2, NP, PA, PB1, and PB2 genes of the A/Ann Arbor $/ 6 / 60$ mutant and wt viruses were determined directly using the dideoxy chain termination method (Sanger et al., 1977) modified for sequencing from virion RNA (Air, 1979). Bands in two lanes of the reaction were observed occasionally at a single nucleotide position. (These postions are indicated by asterisks in the figures). The darkest band was read as the correct nucle- otide. In addition, the NS and M genes of the wt virus were cloned into pBR322 and sequenced using the chemical sequencing method of Maxam and Gilbert (1980). Results using the chemical method were identical to those using the dideoxy chain termination method (data not shown). The sequences of the HA and NA genes of the AVAnn Arbor/6/60 viruses were not determined because they are irrelevant for producing reassortant candidate vaccine strains. Sequences of $\mathrm{H} 2 \mathrm{~N} 2$ virus genes have been published previously for only the NS, NA, and HA genes. Therefore, each gene sequence of the wt $A / A n n$ Arbor/6/60 virus was also compared with influenza $A(H 3 N 2)$ gene sequences available in the Gen Bank data base at the time of analysis.

\section{NS1 and NS2 sequences}

The smallest RNA segment of influenza virus is 890 nucleotides long and codes for the NS1 and NS2 polypeptides that are found only in infected cells (Inglis et al., 1979; Lamb and Choppin, 1979; Lamb et al., 1980). The functions of NS1 and NS2 are unknown. The complete nucleotide sequences for the NS genes of the A Ann Arbor/6/60 mutant and wt viruses are shown in Fig. 1. Two nucleotide differences were detected between the ca mutant and wt viruses with a coding change at nucleotide 483 in the portion of the gene that encodes NS1 and a noncoding change at nucleotide 813 in the portion of the gene that encodes N.S2. The former nucleotide change encodes an alanine to threonine substitution in the mutant NS1 protein at amino acid 153. Comparison of the sequence we obtained for the $A / A n n$ Arbor $/ 6 / 60$ wt NS gene with the sequence for this gene published previously (Buonagurio et al., 1986) revealed complete agreement, with only one additional change compared to the sequence of the $A$ WSN/33 virus in a region not sequenced previously ( $T$ at nucleotide 35 in both ca and wt A/Ann Arbor/6/60 viruses). Volunteer studies with reassortant candidate vaccine strains having an RNA 8 from the $\mathrm{H} 1 \mathrm{~N} 1$ or $\mathrm{H} 3 \mathrm{~N} 2$ wild-type parent indicated that this gene is not required for attenuation (La Montagne et al., 1983). Studies with single gene reassortants are also consistent with the conclusion that RNA 8 does not contribute significantly to attenuation (Snyder et al., 1987).

\section{$M 1$ and $M 2$ sequence}

RNA segment 7 is 1027 nucleotides long and codes for at least two proteins, M1 and M2 (Alien et al., 1980; Winter and Fields, 1980; Lamb et al., 1981). The M1 protein is a viral structural protein of 252 amino acids. The M2 protein is 97 amino acids in length and, al- 


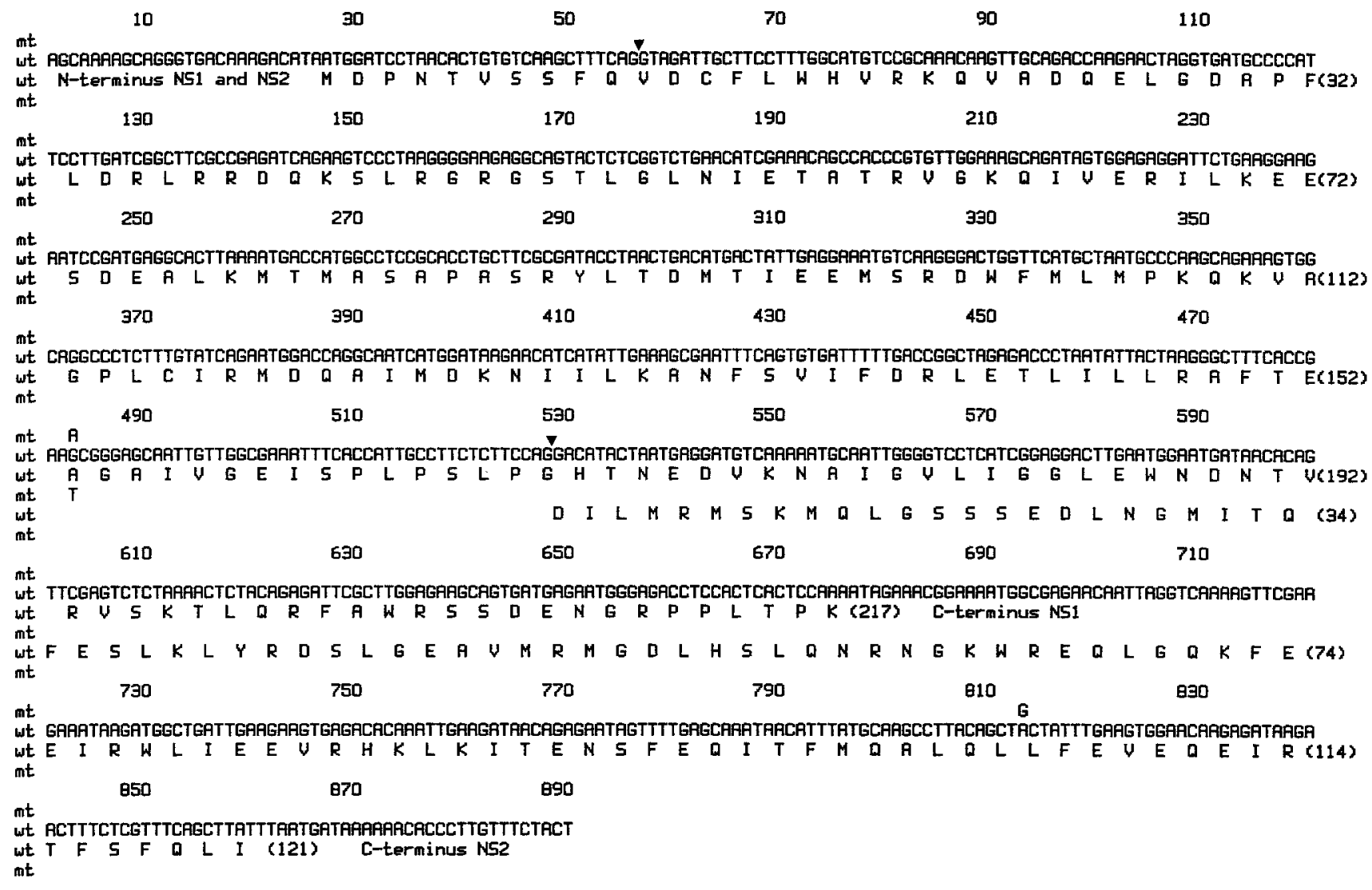

FIG. 1. Nucleotide and protein sequences of RNA segment 8 of the A/Ann/Arbor/6/60 wt and ca mutant viruses. Complete sequences are shown for the wt viruses. Nucleotide changes detected in the mutant RNA are shown above the wt sequence, while predicted amino acid changes in the mutant are shown below the wt sequence. Splice junctions for NS2 are indicated by arrowheads.

though its function is unknown, this protein is known to be inserted into plasma membranes of infected cells (Zebedee et al., 1985). Complete nucleotide sequence data for RNA 7 of A/Ann Arbor/6/60 ca mutant and wt viruses (Fig. 2) demonstrate that there was a single difference ( $G$ to $T$ ) at nucleotide 969 . This nucleotide substitution encodes a change from alanine in the wt to serine in the mutant at amino acid 86 of the M2 protein. Comparison of the Ann Arbor/6/60 M2 sequences with those of other strains indicated that the $\mathrm{M} 2$ genes of the three other wt human strains sequenced to date have alanine at amino acid 86 of M2. This amino acid has been identified as one that varies between human and avian influenza strains (Buchler-White et al., 1986). Amino acid 86 is a part of the trypsin-sensitive carboxyterminal tail (Zebedee et al., 1985). One ca candidate vaccine strain, CR 31 Clone 3 , that received the segment 7 from its wt parent in addition to the HA and NA genes (Cox et al., 1979) was attenuated in seronegative adult volunteers (La Montagne et al., 1983), but was less restricted in its replication in humans than a similar reassortant with segment 7 from the ca parent (Murphy et al., 1981). In addition, a reassortant with only the genes encoding the PA, M1, and $\mathrm{M} 2$ proteins from the ca A Ann Arbor/ $6 / 60$ virus was as attenuated in human volunteers as another reassortant virus having all but the HA and NA genes from the ca donor virus (Snyder et al., 1985). Further studies with single segment reassortant viruses also suggest that either the $\mathrm{M} 1$ or M2 proteins may play a role in attenuation (Snyder et al., 1987). Sequence data presented here suggest that the M2 protein may be responsible for the observed biological findings.

\section{NP sequence}

The nucleoprotein gene [RNA segment 6 of the $A$ Ann Arbor/6/60 viruses under electrophoretic conditions used to separate RNA (Cox et al., 1985)] is 1565 nucleotides in length and encodes a basic structural protein of 498 amino acid residues that specifically interacts with RNA molecules to form ribonucleoprotein complexes (Winter and Fields, 1981; Huddelston and Brownlee, 1982) and has sequences that direct its migration into the nuclei of infected cells (Davey et al, 1985). Three nucleotide changes were detected in the 


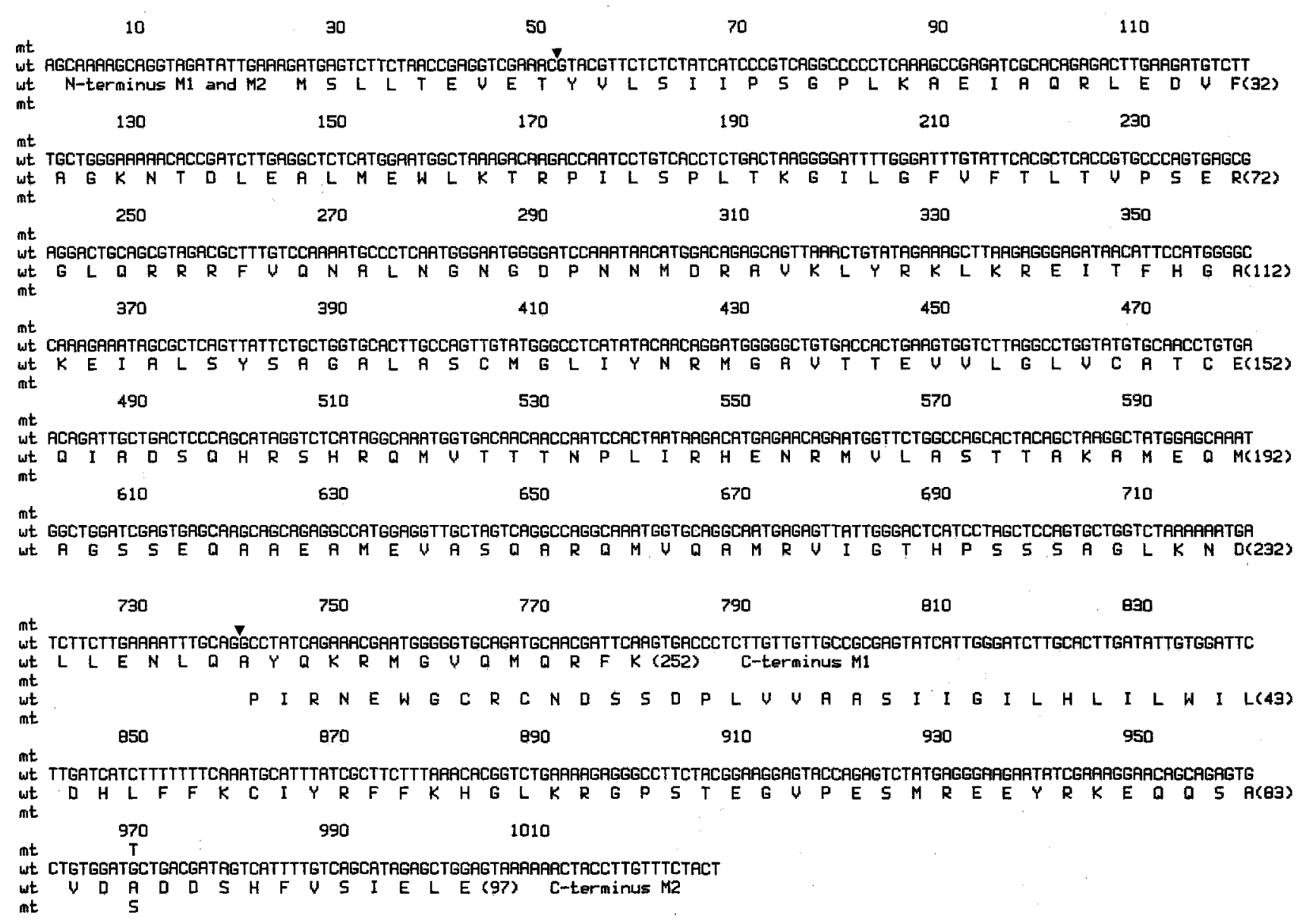

Fig. 2. Nucleotide and protein sequences of RNA segment 7 of the A/Ann/Arbor/6/60 wt and ca mutant viruses. Complete sequences are shown for the wt viruses. Nucleotide changes detected in the mutant RNA are shown above the wt sequence, while predicted amino acid changes in the mutant are shown below the wt sequence. Splice junctions for $\mathrm{M} 2$ are indicated by arrowheads.

mutant NP gene sequence (Fig. 3) A change at nucleotide 113 encodes an amino acid substitution from threonine in the wt to asparagine in the ca mutant at amino acid 23, and a change at nucleotide 146 encodes an amino acid substitution from aspartic acid in the wt to glycine in the ca mutant at amino acid 34 . The change at nucleotide 113 is not present in NP genes of other influenza viruses sequenced, while the change at nucleotide 146 is also present in the highly passaged laboratory strain, A/PR/8/34. The other change in the NP gene of the mutant is the insertion of a single $A$ nucleotide in an A-rich region (1545-1550) that is near the putative polyadenylation signal (Robertson et al., 1981). This insertion may not be important because other influenza virion RNA segments have poly(U) tracts of varying lengths in corresponding positions. Although a ca NP gene was present in all the candidate vaccine strains we examined (Cox et al., 1986), no compelling genetic evidence exists to show that the NP genes of the ca mutant and wt A/Ann Arbor/6/60 viruses are associated with different phenotypic properties (Snyder et al., 1987); therefore, the significance of the mutations in RNA 6 is unknown.

\section{PA sequences}

RNA segment 3 is 2233 nucleotides in length and encodes an acidic polymerase protein (PA) 716 amino acids in length (Fields and Winter, 1982; Bishop et al., 1982b; Robertson et al., 1984). The complete nucleotide sequences for the PA genes of AVAnn Arbor/6/60 mutant and wt viruses are presented in Fig. 4 . Four nucleotide changes were detected in the mutant gene, with two of these changes located in the same codon. A change at nucleotide 20 ( $U$ to $C$ ) is in the noncoding region. Comparison of the A/Ann Arbor/6/60 sequences with published sequences revealed that $A /$ $\mathrm{PR} / 8 / 34$ and the Rostock strain of fowl plague virus have $\mathrm{C}$ at nucleotide 20 (Fields and Winter, 1982; Robertson et al., 1984), while ANT/60/68, like the A/Ann 


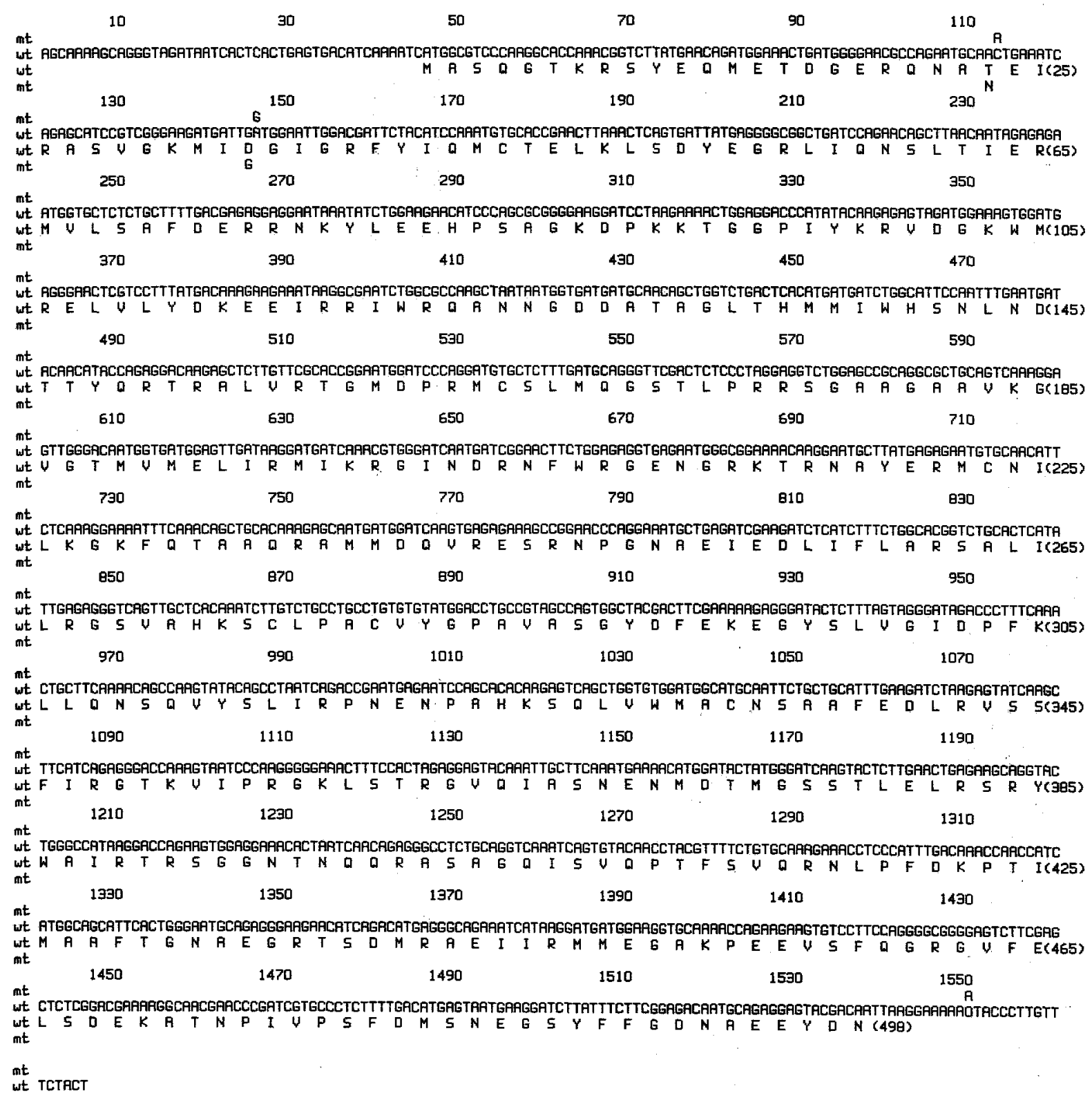

FIG. 3. Nucleotide and protein sequences of RNA segment 6 (NP) of the AAnn/Arbor/6/60 wt and ca mutant viruses. Complete sequences are shown for the wt viruses. Nucleotide changes detected in the mutant RNA are shown above the wt sequence, while predicted amino acid changes in the mutant are shown below the wt sequence. The single nucleotide insertion is indicated by a 0 in the wt sequence at position 1550 .

Arbor/6/60 wt, has $\cup$ (Bishop et al., 1982b). Thus it seems unlikely that this $\mathrm{U}$ to $\mathrm{C}$ change is important in attenuation. It is possible, however, that this change could alter base pairing of the ends of the RNA segment or polymerase recognition (Skehel and Hay, 1978; Robertson, 1979; Stoeckle et al., 1987). A single base change in the noncoding region of the poliovirus 3 genome has been shown to affect attenuation (Evans et al., 1985). A change from $A$ to $G$ at nucleotide 1861 encodes a lysine to glutamic acid substitution at amino acid 613. While this is a change from a basic to an acidic residue, it is not likely by itself to be involved in attenuation because comparison with other sequences revealed that $\mathrm{A} / \mathrm{PR} / 8 / 34, \mathrm{~A} / \mathrm{FPV} /$ Rostock $/ 34$, and $\mathrm{ANT} / 60 / 68$, like the A/Ann Arbor/6/60 mutant virus, all have glutamic acid at residue 613 . The two other changes are in the same codon (TTA to CCA at nucleotides 2167 and 2168 ), resulting in a predicted amino acid substitution at residue 715 (the penultimate amino acid in the PA protein) from leucine in the wt to 


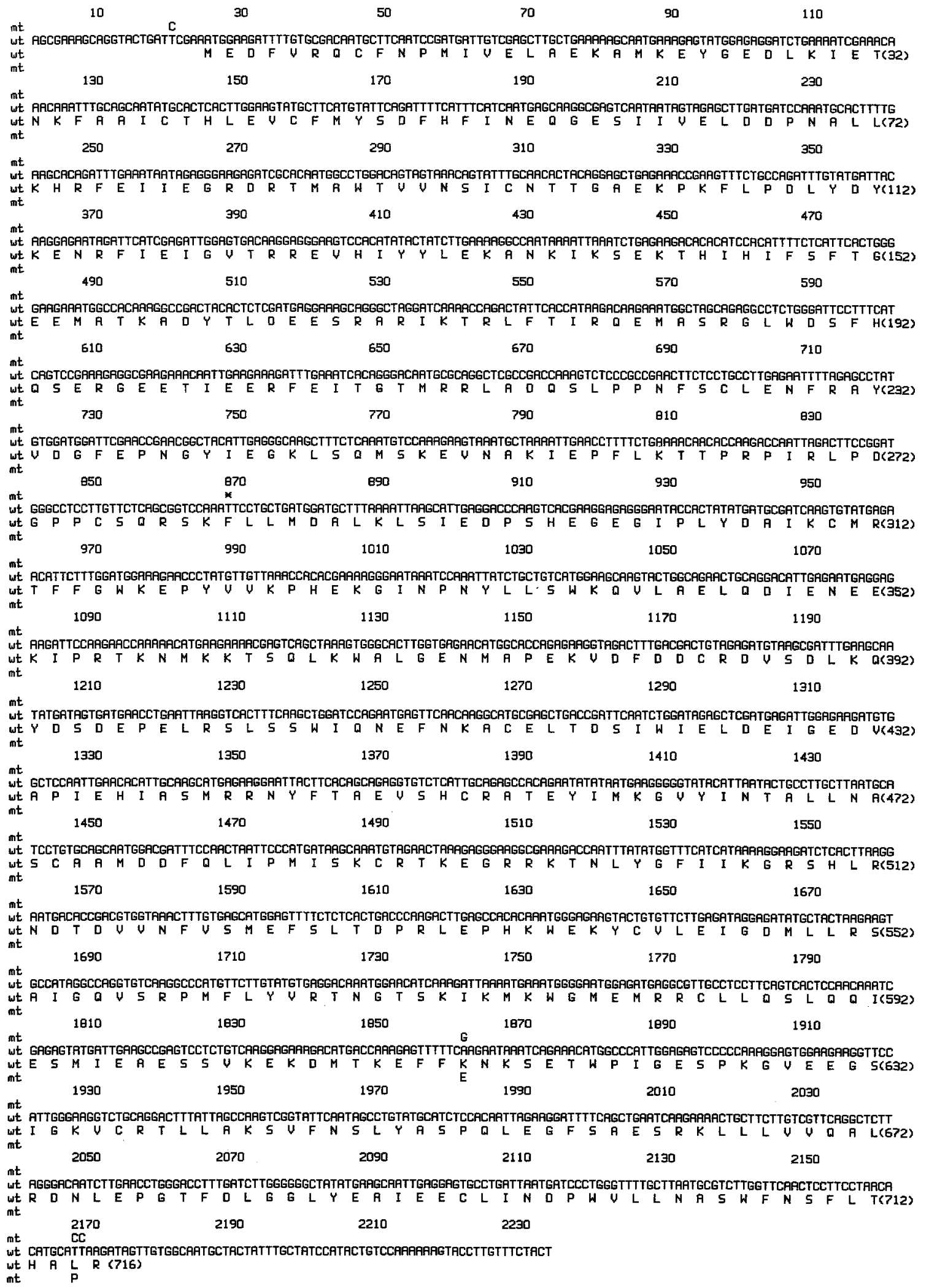

FIG. 4. Nucleotide and protein sequences of RNA segment 3 of the A/Ann/Arbor/6/60 wt and ca mutant viruses. Complete sequences are shown for the wt viruses. Nucleotide changes detected in the mutant RNA are shown above the wt sequence, while predicted amino acid changes in the mutant are shown below the wt sequence. 
proline in the ca mutant. Although two nucleotide changes were found in the same codon, only a single nucleotide change from CCA to CTA is required for reversion back to leucine by the mutant. The other three influenza viruses sequenced to date have leucine at residue 715 of their PA proteins. The PA gene has been demonstrated to be involved in the cold-adaptation and attenuation properties of the mutant (Odagiri et al., 1986; Snyder et al., 1985, 1987), so this leucine to proline change may be relevant to virus phenotype.

\section{PB1 sequence}

RNA segment 2 is 2341 nucleotides in length and encodes a basic polymerase protein (PB1) 757 amino acids in length (Winter and Fields, 1982; Bishop et al., 1982a; Sivasubramanian and Nayak, 1982). Seven nucleotide differences were detected between the A/Ann Arbor/6/60 mutant and wt PB1 gene sequences (Fig. 5). Changes at nucleotides 123 and 486 were noncoding changes. Four coding changes were found at nucleotides $1195,1395,1766$, and 2005 followed by a noncoding change at nucleotide 2019. The four coding changes result in amino acid substitutions of lysine to glutamic acid at amino acid 391, glutamic acid to aspartic acid at amino acid 457, glutamic acid to glycine at amino acid 581, and alanine to threonine at amino acid 661 . None of these four changes exists in the three other wild-type PB1 genes sequenced to date, so any or all of them may be involved in the biological properties of the virus. Because RNA 2 of the mutant was absent in several ca reassortant vaccines that were fully attenuated (La Montagne et al., 1983), its role in attenuation has been questioned. Earlier genetic evidence (Cox et al., 1981) and more recent evidence using single gene reassortants in several animal models, however, suggest that mutations in RNA 2 may contribute to the temperature-sensitive and attenuation phenotypes of the ca $A / A n n$ Arbor/6/60 virus (Snyder et al., 1987).

\section{PB2 sequence}

RNA segment 1 is 2341 nucleotides in length and encodes a basic polymerase polypeptide (PB2) of 759 amino acids (Fields and Winter, 1982; Kaptein and Nayak, 1982; Jones et al., 1983; Roditi and Robertson, 1984). The complete nucleotide sequences of the $A$ Ann Arbor/6/60 mutant and wt PB2 genes are shown in Fig. 6. Seven nucleotide differences were detected between mutant and wild-type sequences, at nucleotides 141, 426, 821, 1182, 1212, 1353, and 1923. Only the A to $G$ change at nucleotide 821 encodes an amino acid change, from asparagine in the wt to serine in the mutant at amino acid 265. Examination of the other PB2 sequences available for other wt influenza A viruses revealed that asparagine is present at amino acid 265 in each case. However, a lower passage $\left(E_{3}\right)$ A/Ann Arbor/6/60 wild-type virus sequenced in another laboratory, like the ca mutant, had serine at amino acid 265 (Herlocher, personal communication). The other six changes, $A$ to $G, U$ to $C, A$ to $U, C$ to $U, U$ to $G$, and A to $G$ at nucleotides $141,426,1182,1212,1353$, and 1923 , respectively, are all silent mutations within the coding region. All AAnn Arbor/6/60 ca reassortant vaccines tested in clinical trials thus far (except single segment reassortants) derive their PB2 gene from the ca parent (Cox et al., 1986; Maassab, personal communication), and early genetic data indicated that RNA 1 may be involved in the temperature sensitivity of the mutant (Spring et al., 1977). More recent results using single segment reassortant viruses also indicate that RNA 1 contributes to the temperature-sensitive phenotype of the ca mutant (Snyder et al., 1987).

\section{DISCUSSION}

Here we describe the complete nucleotide sequences for the genes encoding the NS1, NS2, M1, M2, NP, PA, PB1, and PB2 proteins of the coldadapted and wild-type A/Ann Arbor/6/60 (H2N2) viruses. Few sequences are published for genes of $\mathrm{H} 2 \mathrm{~N} 2$ viruses. Such data are of evolutionary and epidemiologic significance because $\mathrm{H}_{2} \mathrm{~N} 2$ viruses are proposed to be the immediate ancestors of the H3N2 subtype (Scholtissek et al., 1978; Nakajima et al., 1982). Comparisons between the wt A/Ann Arbor/6/60 gene sequences and those published previously for the $\mathrm{H} 3 \mathrm{~N} 2$ viruses $\mathrm{A} / \mathrm{NT} / 60 / 68$ or $\mathrm{A} / \mathrm{Udorn} / 72$ indicate that yearly rates of mutation of $0.36,0.24,0.28,0.40,0.68$, and $0.49 \%$ occurred for the NS, M, NP, PA, PB1, and PB2 gene segments, respectively. These observations are consistent with the derivation of these genes in the $\mathrm{H} 3 \mathrm{~N} 2$ viruses from previously circulating $\mathrm{H} 2 \mathrm{~N} 2$ viruses.

We have identified 24 nucleotide differences between the A/Ann Arbor/6/60 ca mutant donor strain and its wt parent (Table 1). These 24 nucleotide changes constitute $0.2 \%$ of the total number of nucleotides sequenced. Our previous estimate (based on $T_{1}$ oligonucleotide mapping studies) that as many as $40-$ 60 nucleotide changes might have occurred in the total genome of the ca mutant (Cox et al., 1986) was inaccurate. Comparison of deduced amino acid sequences for the parental and mutant viruses revealed 11 amino acid differences or $0.26 \%$ of the total number of amino acids (Table 1). Sequences for four other pairs of wt and attenuated viruses have been compared, and the 
10

30

50

70

90

110

st RGCGAFAGCAGGCRRACCATTTGARTGGRTGTCAATCCGACCTTACTTTTCTTGAARGTTCCAGCGCARAATGCCATARGTACTRCATTCCCTTATACTGGAGATCCTCCATACAGCCAT wt $M$ D N N P T L L F L K U P A Q N A I S T T F P Y T G D P P Y S H(32)

nit 130

150

170

190

210

230

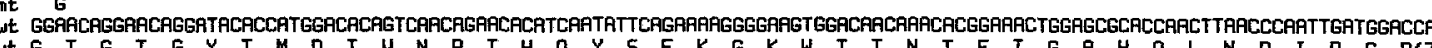
int $250 \quad 270$

290

310

390

350

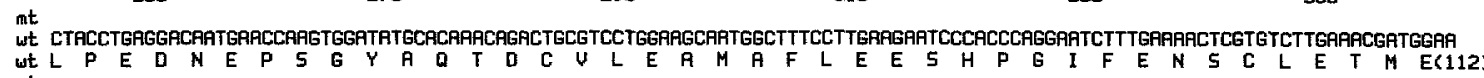
mt 370 390

410

430

450

470

wt GTTATTCAACRAACARGGGTGGRCAAACTGACCCARGGTCGTCAGACCTATGATTGGACATTGARCAGARATCAGCCGGCTGCARCTGCGCTRECCAACACTATAGRGGTCTTCAGATCG

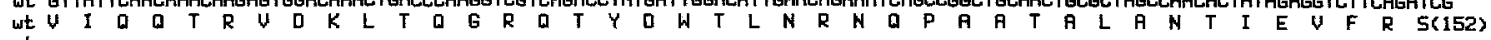
mit 490 $510 \quad 530$

550 570

590

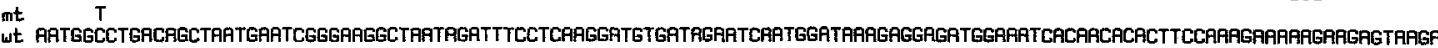

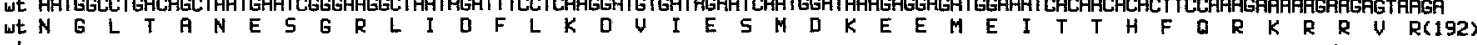
mt 610 630

650

670

690

710

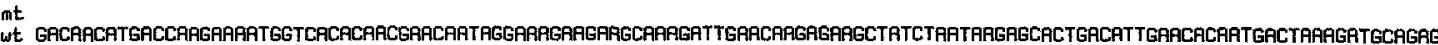

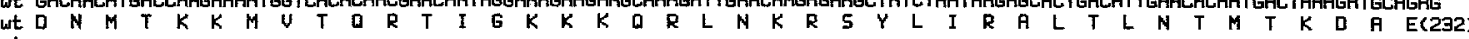
$\begin{array}{cccccc}\text { mt } & 730 & 750 & 770 & 790 & 010\end{array}$

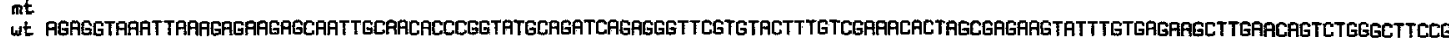

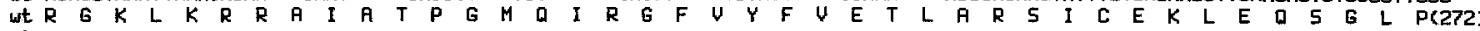
$\begin{array}{llllll}\text { int } & 850 & 070 & 890 & 910 & 990\end{array}$

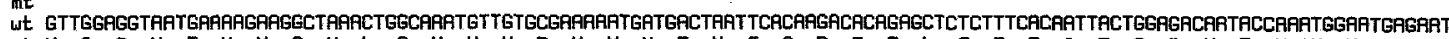

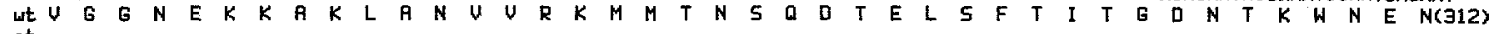
(N) $990 \quad 1010$ 1030

1050

1070

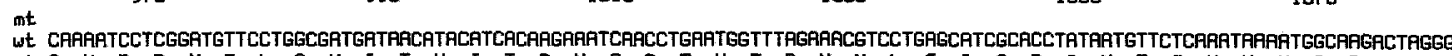

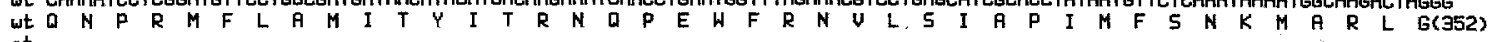
mt 1090 $1110 \quad 1130$

1150

1170

1190

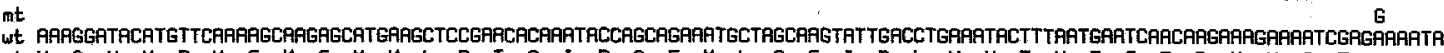

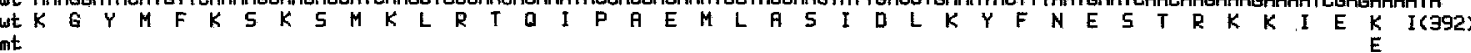

1230

1250

1270

1290

1310

wt. AGGCCTCTCCTARTAGATGGCACAGTCTCATTGAGTCCTGGAATGATGATGGECATGTTCAPCATGCTAAGTACAGTCTTRGGAGTCTCFATCCTGAATCTTGGACAAARGAAGTACACC

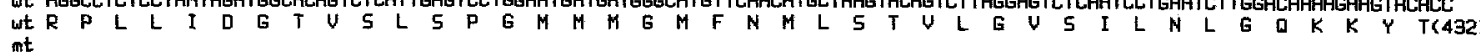
1390
1350
1970
1390
1410
1430

wt ARAACRACATACTGGTGGEACGGACTCCARTCCTCTGATGACTTCGCCCTCATAGTGARTGCACCARFTCATGA'GGGATACAAGCAGGGGTGGATRGATTCTACAGARCCTECARGCTA

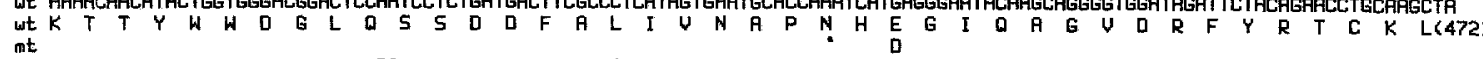
1450
1470
1490
1510
1530
1550

wt GTCGGAATCARTATGAGCARARAGARGTCCTACATARATAEGACAGGGACATTTGRATTCACAAGCTTTTTCTATCGCTATGGGTTTGTAGCCARTTTTAGCATGGAGCTGCCCAGCTTT

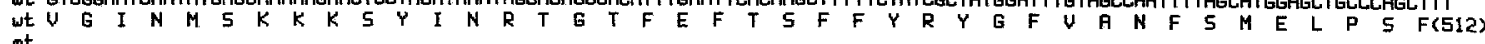
mt 1570

$$
1590
$$

1510

1690

1650

1670

wt GGRGTGTCTGGAATTARTGARTCGGCTGATATGRGCATTGGGGTAACAGTGATRARGARCAACATGATARACAATGACCTTGGGCCAGCAACAGCCCAACTGGCTCTTCARCTRTTCATC

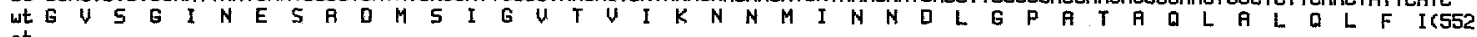
1690 1730 1750 $\mathrm{G}^{1770}$ 1790

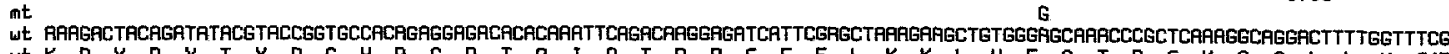

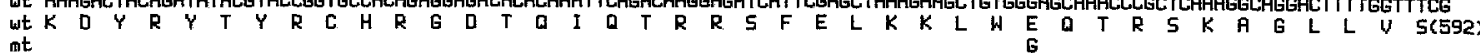

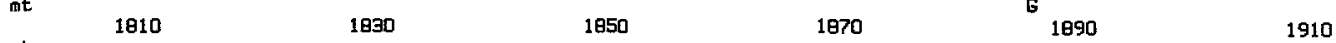
wt GATGEAGGACCAAPCTTATACFATATCCGGARTCTCCACATTCCAGRAGTCTGCT TGAAGTGGGAGCTAATGEATGPAGACTATCAGGGGAGGCTTTGTRATCCCCTGAATCCATTTGTC

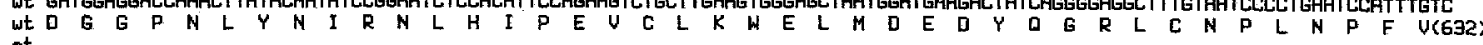

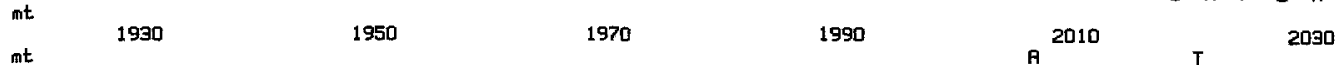
wt AGTCATARGGRGATTGAGTCTGTARACRATGCTGTGGTRATGCCAGCTCACGGTCCAGCCFAGAGCATGGARTATGATGCTGTTGCTACTRCACACTCCTGGATCCCTARGAGGACCGC wt $S$ H K

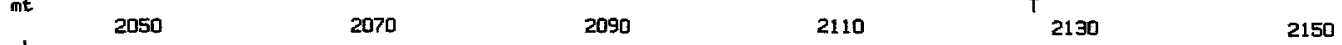
wt TCCATTCTCAACACAPGCCAPAGGGGATTCTTGARGATGAACAGATGTATCAGARGTGTTGCARTCTATTCGAGARATTCTTCCCTAGCAGTTCGTPCAGERGACCRGTTGGAATTTCC wt 5 I $L$ L mt
2170
2190
2210
2230
2250
2270

wt AGCATGGTGGRGGCCATGETGTCTAGGGCCCEGATTGATGCACGGATTGACTTCGRGTCTGGACGGATTRAGARAGAGGAGTTCGCTGAGRTCATGRAGRTCTETTCCACCATTGRAGAG

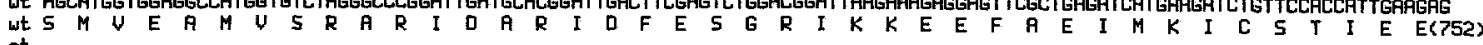
mit $2290 \quad 2390$

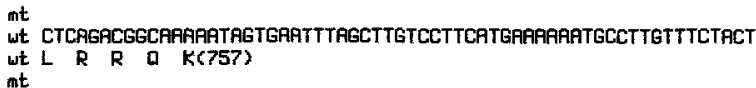

FIG. 5. Nucleotide and protein sequences of RNA segment 2 of the A/Ann/Arbor/6/60 wt and ca mutant viruses. Complete sequences are shown for the wt viruses. Nucleotide changes detected in the mutant RNA are shown above the wt sequence, while predicted amino acid changes in the mutant are shown below the wt sequence. 


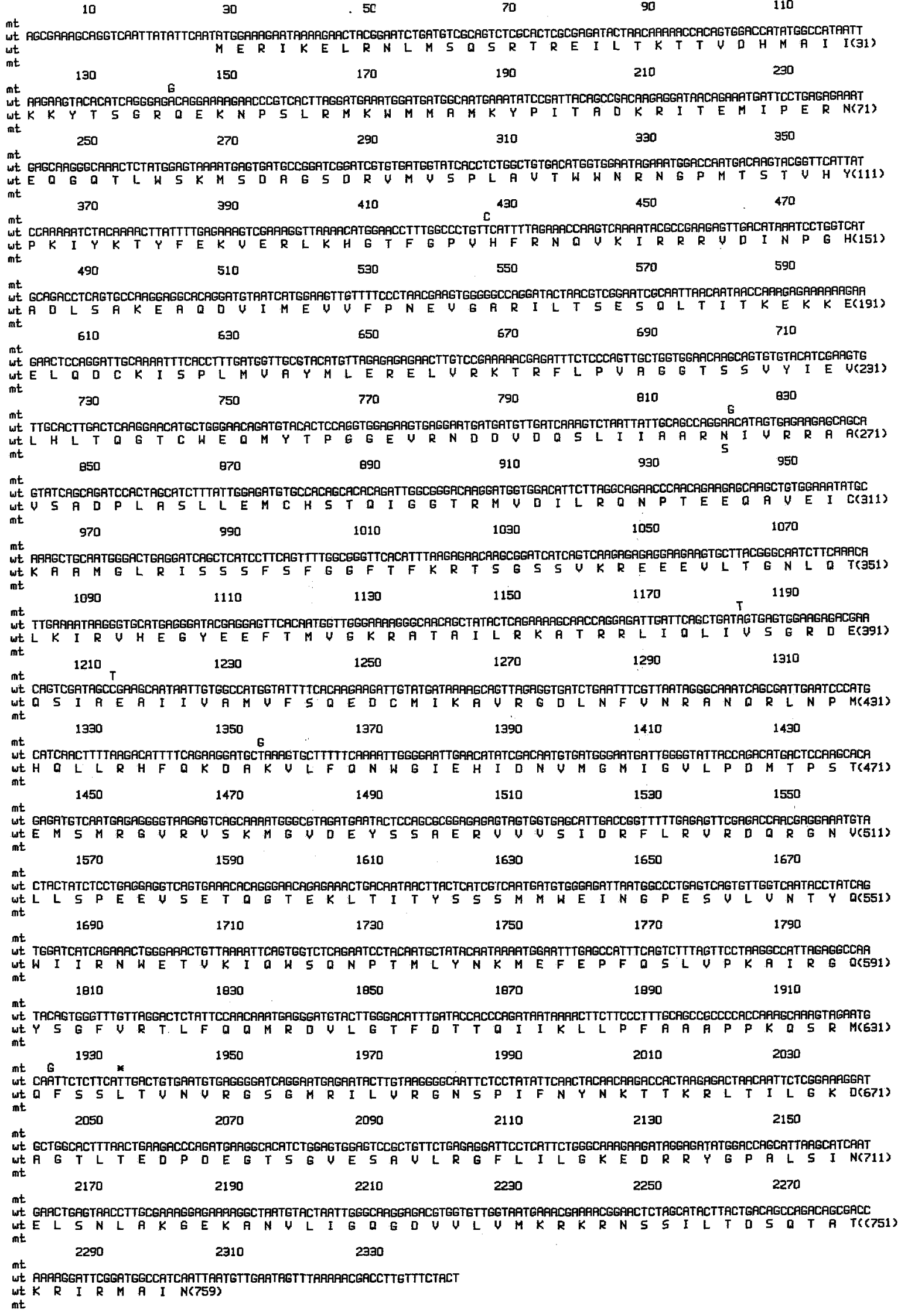

FIG. 6. Nucleotide and protein sequences of RNA segment 1 of the A/Ann/Arbor/6/60 wt and ca mutant viruses. Complete sequences are shown for the wt viruses. Nucleotide changes detected in the mutant RNA are shown above the wt sequence, while predicted amino acid changes in the mutant are shown below the wt sequence. 
TABLE 1

Summary of Comparative. Sequence Data for A/Ann Arbor/6/60 Wild-Type and Mutant Viruses

\begin{tabular}{|c|c|c|c|c|c|c|c|}
\hline \multirow{2}{*}{$\begin{array}{l}\text { RNA } \\
\text { segment }\end{array}$} & \multirow[b]{2}{*}{ No. of changes } & \multicolumn{2}{|c|}{ Nucleotide change } & \multicolumn{2}{|c|}{ Position changed } & \multicolumn{2}{|c|}{ Amino acid change } \\
\hline & & wt & MT & Nucleotide & a.a. & wt & MT \\
\hline 1 (PB2) & $\begin{array}{l}1 \text { Coding change } \\
4 \text { Noncoding changes }\end{array}$ & $\begin{array}{l}\text { AAC } \\
\text { AGA } \\
\text { GTI } \\
\text { ATA } \\
\text { GCC } \\
\text { GCI } \\
\text { CAA }\end{array}$ & $\begin{array}{l}\text { AGC } \\
\text { AGG } \\
\text { GTC } \\
\text { ATI } \\
\text { GCI } \\
\text { GCG } \\
\text { CAG }\end{array}$ & $\begin{array}{r}821 \\
141 \\
426 \\
1182 \\
1212 \\
1353 \\
1923\end{array}$ & $\begin{array}{l}265 \\
- \\
- \\
- \\
- \\
-\end{array}$ & $\begin{array}{r}\text { Asn } \\
- \\
- \\
- \\
- \\
-\end{array}$ & $\begin{array}{c}\text { Ser } \\
- \\
- \\
- \\
- \\
-\end{array}$ \\
\hline 2 (PB1) & 3 Noncoding changes & $\begin{array}{l}\text { AAA } \\
\text { GAG } \\
\text { GAG } \\
\text { GCT } \\
\text { GGA } \\
\text { GGC } \\
\text { TCC }\end{array}$ & $\begin{array}{l}\text { GAA } \\
\text { GAI } \\
\text { GGG } \\
\text { ACT } \\
\text { GGG } \\
\text { GGI } \\
\text { TCI }\end{array}$ & $\begin{array}{r}1195 \\
1395 \\
1766 \\
2005 \\
123 \\
486 \\
2019\end{array}$ & $\begin{array}{l}391 \\
457 \\
581 \\
661 \\
- \\
- \\
-\end{array}$ & $\begin{array}{l}\text { Lys } \\
\text { Glu } \\
\text { Glu } \\
\text { Ala } \\
\begin{array}{r}- \\
-\end{array}\end{array}$ & $\begin{array}{l}\text { Glu } \\
\text { Asp } \\
\text { Gly } \\
\text { Thr } \\
- \\
- \\
-\end{array}$ \\
\hline $3(\mathrm{PA})$ & $\begin{array}{l}2 \text { Coding changes } \\
1 \text { Noncoding change }\end{array}$ & $\begin{array}{l}\text { AAG } \\
\frac{\text { IIA }}{I}\end{array}$ & $\begin{array}{l}\text { GAG } \\
\frac{\mathrm{C} C A}{\mathrm{C}}\end{array}$ & $\begin{array}{c}1861 \\
2167-8 \\
20\end{array}$ & $\begin{array}{l}613 \\
715 \\
-\end{array}$ & $\begin{array}{l}\text { Lys } \\
\text { Leu } \\
\text { Noncoding }\end{array}$ & $\begin{array}{l}\text { Glu } \\
\text { Pro }\end{array}$ \\
\hline $\begin{array}{l}\text { Region } \\
\quad 6 \text { (NP) }\end{array}$ & 2 Coding changes & $\mathrm{AC} T$ & AAT & 113 & 23 & Thr & \\
\hline & 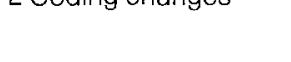 & $\mathrm{GAT}$ & GGT & 146 & 34 & Asp & Gly \\
\hline & $\begin{array}{l}\text { Single nucleotide } \\
\text { insertion }\end{array}$ & GAAAAAT & GAAAAAAT & 1550 & - & Noncoding & \\
\hline Region & & & & & & & \\
\hline $\begin{array}{r}7(\mathrm{M} 1) \\
(\mathrm{M} 2)\end{array}$ & 1 Coding change & GCT & ICT & $\overline{969}$ & $\overline{86}$ & $\mathrm{Ala}^{-}$ & $\overline{\text { Ser }}$ \\
\hline $\begin{array}{r}8 \text { (NS1) } \\
\text { (NS2) }\end{array}$ & $\begin{array}{l}1 \text { Coding change } \\
1 \text { Noncoding change }\end{array}$ & $\begin{array}{l}\text { GCG } \\
\text { CTA }\end{array}$ & $\begin{array}{l}\triangle C G \\
C T G\end{array}$ & $\begin{array}{l}483 \\
813\end{array}$ & $\begin{array}{l}153 \\
-\end{array}$ & Ala & Thr \\
\hline
\end{tabular}

total number of nucleotide or amino acid changes acquired during attenuation represents less than $1 \%$ of the genome or protein in each case (reviewed by Cohen et al., 1987). There are more differences between wt and ca A/Ann/Arbor/6/60 viruses than between wt and vaccine strains of poliovirus 3 but fewer differences than between wt and vaccine strains of poliovirus 1, yellow fever virus, hepatitis A virus $\mathrm{HM}-175$ (Cohen et al., 1987), and influenza B viruses (DeBorde et al., 1988). It seems clear that relatively few changes are present in a variety of attenuated RNA viruses. Because viral RNA genomes are extremely heterogeneous (Domingo et al., 1985), sequencing of a viral RNA template results in a consensus sequence consisting of the base present at the greatest frequency at each nucleotide position. Sequence variations present in minor subpopulations remain undetected. These low frequency sequence variations, however, would not be expected to contribute significantly to the phenotypic properties of the virus.

During the many clinical studies conducted with investigational ca vaccines derived from the ca AVAnn Ar- bor/6/60 virus, over 900 isolates from human volunteers have been tested for the phenotypic properties of cold-adaptation and temperature-sensitivity, and no true revertants have been detected (Murphy et al., 1980; Wright et al., 1982; Maassab, personal communication). Similarly, reversion has not been demonstrated in ferrets (Maassab et al., 1982). This is in contrast to results with investigational ts influenza live attenuated vaccines (Murphy et al., 1980; Tolpin et al., 1981). It is likely, therefore, that more than one of the mutations identified here are biologically important, so that if reversion or suppression of one mutation occurs, attenuation conferred by other independent mutation(s) remains. This is supported by data obtained with single gene reassortants (Snyder et al., 1987). Thus, all available data support the previous suggestion that candidate vaccine strains be selected on the basis of having six internal genes of the mutant donor parent since multiple mutations throughout the genome might confer increased stability (Cox et al., 1979, 1986).

Now that the precise nature of the mutations in the A/Ann Arbor/6/60 ca donor strain has been deter- 
mined, it would be relatively simple to sequence rapidly the relevant areas of each gene in viruses prepared for human use or in viruses recovered from infected volunteers to monitor the stability of these mutations during production and use of ca reassortant candidate vaccines. This approach would not detect suppressor mutations (Scholtissek, 1984), however, and monitoring of phenotypic properties would also be important.

Because it would be expected that a combination of nonspecific mutations and mutations specific for the phenotypic properties of the ca A/Ann Arbor/6/60 virus might occur during the process of cold-adaptation, we have attempted to deduce the likelihood that the mutations detected are involved in the phenotypic properties of the virus. After taking into consideration the available data, we suggest that the changes in the ca AVAnn Arbor/ $6 / 60$ virus that are of particular interest for future study are as follows: (1) the alanine to serine change at amino acid 86 in the M2 protein, (2) the leucine to proline change at amino acid 715 in the PA protein, (3) the asparagine to serine change at amino acid 265 in PB2, and (4) any or all of the four changes in the PB1 protein. While it is useful to attempt to identify those changes most likely to be involved in the phenotypic properties of the ca virus, conclusions made at this time must be viewed as preliminary for the following reasons: (1) Some contradictions appear in results from genetic complementation or recombination experiments that used different ts mutant sets (Spring et al., 1977; Reeve et al., 1980a; Cox et al., 1981). (2) Conclusions about the genetic basis of attenuation made with single segment reassortants may not apply for different wild-type parents. (3) Mixing polymerase genes of two human influenza viruses may in itself attenuate a reassortant (Florent, 1980). (4) Some of the mutations in the A Ann Arbor/6/60 ca mutant that are also present in other wt sequences may be biologically significant in the context of other sequence changes. Experiments that use site-specific mutagenesis and DNA expression systems to demonstrate the effect of a particular mutation in a functional assay as well as experiments to obtain and sequence phenotypic revertants will be necessary to further define the biological importance of the mutations reported here. Until definitive studies are complete, it is advisable that, to minimize the risk of reversion to virulence, vaccines used in open populations contain all genes except those coding for $\mathrm{HA}$ and NA from the ca parent.

\section{ACKNOWLEDGMENTS}

We thank Ms. Judith Galphin for expert technical assistance and Ms. Denise Johnson for manuscript preparation. We also thank Louise Herlocher for providing prepublication sequences of RNA 1 of the A Ann Arbor/6/60 ca and wt viruses.

\section{REFERENCES}

AIR, G. M. (1979). Nucleotide sequence coding for the "signal peptide" and N-terminus of the hemagglutinin from an Asian (H2N2) strain of influenza virus. Virology 97, 468-472.

Allen, H., McCauley, J., Waterfield, M., and Gething, M. J. (1980). Influenza virus RNA segment 7 has the coding capacity for two polypetides. Virology $107,548-551$.

BELSHE, R. B., and VAN VORIS, L. P. (1984). Cold-recombinant influenza A/California/10/78 (H1N1) virus vaccine (CR-37) in seronegative children: Infectivity and efficacy against investigational challenge. J. Infect. Dis. 149, 735-740.

Bishop, D. H. L., Huddelston, J. A., and Brownlee, G. G. (1982a). The complete nucleotide sequence of RNA segment 2 of influenza ANNT/60/68 and its encoded P1 protein. Nucleic Acids Res. 10, $1335-1343$.

Bishop, D. H. L., Jones, K. L., Huddelston, J. A., and Brownlee G. G. (1982b). Influenza A virus evolution: Complete sequences of influenza ANNT/60/68 RNA segment 3 and its predicted acidic $p$ polypeptide compared with those of influenza A/PR/8/34. Virology $120,481-489$.

Buchler-White, A., NAeVe, C. W., and Murphy, B. R. (1986). Characterization of a gene coding for $M$ proteins which is involved in hostrange restriction of an avian influenza virus in monkeys. J. Virol. 57 , $697-700$.

Buonagurio, D. A., Nakada, S., Parvin, J. D., Krystal, M., Palese, P., and FITCH, W. M. (1986). Evolution of human influenza $A$ viruses over 50 years: Rapid, uniform rate of change in NS gene. Science 232, 980-982.

CATE, T. R., and COuch, R. B. (1982). Live influenza AVictoria/75 (H3N2) virus vaccines: Reactogenicity, immunogenicity and protection against wild-type virus challenge. Infect. Immun. 38, 141 146.

Clements, M. L., O'Donnel., S., Levine, M. M., Chanock, R. M., and MURPHY, B. R. (1983). Dose response of A/Alaska/6/77 (H3N2) cold-adapted reassortant vaccine virus in adult volunteers: Role of local antibody in resistance to infection with vaccine virus. Infect. Immun. 40, 1044-1051.

Cohen, J. I., Rosenblum, B., Ticehurst, J. R., Daemer, R., Feinstone, S., and PURCELL, R. H. Comparison of the nucleotide sequence of wild-type hepatitis $A$ virus and its attenuated candidate vaccine derivative. (1987). In "Modern Approaches to New Vaccines" (R. M. Chanock, R. A. Lerner, F. Brown, and H. Ginsberg, Eds.), pp. 327-331. Cold Spring Harbor Laboratory, Cold Spring Harbor, NY.

Couch, R. B., Quarles, J. M., CATE, T. R., and ZahradniK, J. M. (1986). Clinical trials with live cold-reassortant influenza virus vaccines. In "Options for the Control of Influenza" (A. P. Kendal and P. A. Patriarca, Eds.), pp. 223-241. A. R. Liss, New York.

Cox, N. J. (1986). Progress and limitations in understanding the genetic basis for attenuation of live attenuated influenza vaccines. In "Options for the Control of Influenza" (A. P. Kendal and P. Patriarca, Eds.), pp. 207-221. A. R. Liss, New York.

COX, N. J., and KENDAL, A. P. (1984). Genetic stability of AVAnn Arbor/ 6/60 cold-mutant (temperature-sensitive) live influenza virus genes: Analysis by oligonucleotide mapping of recombinant vaccine strains before and after replication in volunteers. J. Infect. Dis. $149,194-200$

Cox, N. J., Kendal, A. P., MaAssab , H. F., Scholtissek, C., and SPRING, S. B. (1981). Genetic synergism between matrix protein and polymerase protein required for temperature sensitivity of the cold-adapted influenza AVAnn Arbor/6/60 mutant virus. In "The Replication of Negative Strand Viruses" (D. H. L. Bishop and R. W. Compans, Eds.), pp. 405-413. Elsevier North Holland, New York. 
Cox, N. J., Kendal, A. P., Shilov, A. A., Alexandrova, G. I., GHendon, Y. Z., and KLIMOV, A. I. (1985). Comparative studies of A/Lenin$\mathrm{grad} / 134 / 57$ wild-type and 47-times passaged cold-adapted mutant influenza viruses: Oligonucleotide mapping and RNA/RNA hybridization studies. J. Gen. Virol. 66, 1697-1707.

Cox, N. J., Kitame, F., Klimov, A., KoenneCKe, I., and Kendal, A. P. (1986). Comparative studies of wild-type and cold-mutant (temperature-sensitive) influenza virus: Detection of mutations in all genes of the A/Ann Arbor/6/60 (H2N2) mutant vaccine donor strain. Microbiol. Pathogen. 1, 387-397.

Cox, N. J., MaAssab, H. F., and KendaL, A. P. (1979). Comparative studies of wild-type and cold-mutant (temperature-sensitive) influenza viruses: Nonrandom reassortment of genes during preparation of live vaccine candidates by recombination at $25^{\circ}$ between recent $\mathrm{H} 3 \mathrm{~N} 2$ and $\mathrm{H} 1 \mathrm{~N} 1$ epidemic strains and cold-adapted AVAnn Arbor/6/60. Virology 97, 190-194.

Davenport, F. M., Hennessy, A. V., Maassab, H. F., Minuse, E., Clark, L. C., ABrams, G. D., and MitChelL, J. R. (1977). Pilot studies on recombinant cold-adapted live type $A$ and $B$ influenza virus vaccines. J. Infect. Dis. 136, 17-25.

DAVEY, J., DIMMOCK, N. J., and COLMAN, A. (1985). Identification of the sequence responsible for nuclear accumulation of the influenza virus nucleoprotein in Xenopus oocytes. Cel/ 40, 667-675.

DeBorde, D. C., Donabedian, A. M., Herlocher, M. L., Naeve, C. W., and MAASSAB, H. F. (1988). Sequence comparison of wildtype and cold-adapted B/Ann Arbor/1/66 influenza virus genes. $V$ irology $163,429-443$.

DeBorde, D. C., Naeve, C. W., Herlocher, M. L., and MaAssab, H. F. (1986). Resolution of a common RNA sequencing ambiguity by terminal deoxynucleotidyl transferase. Anal. Biochem. 157, 275-282.

Devereaux, J., Haeberli, P., and Smithies, O. (1984). A comprehensive set of sequence analysis programs for the VAX. Nucleic Acids Res. 12, 387-395.

domingo, E., Martinez-Salas, E., Sobrino, F., De La Torre, J. C., Portela, A., Ortin, J., Lopez-Galindez, C., Perez-Brena, P., Villanueva, N., Najera, R., Vande Pol, S., Steinhauer, D., De Polo, N., and HOLLAND, J. (1985). The quasispecies (extremely heterogeneous) nature of viral RNA genome populations: Biological relevance-A review. Gene 40, 1-8.

Evans, D. M. A., Gunn, D., Minor, P. D., SChild, G. C., Cann, A. J., Stanway, G., Almond, J. W., Currey, K., and Malzel, J. V., JR. (1985). Increased neurovirulence associated with a single nucleotide change in a noncoding region of the Sabin type 3 poliovaccine genome. Nature (London) 314, 548-550.

FIELDS, S., and WINTER, G. (1982). Nucleotide sequences of influenza virus segments 1 and 3 reveal mosaic structure of a small viral RNA segment. Cell 28, 303-323.

FLORENT, G. (1980). Gene constellation of live influenza A vaccines: brief report. Arch. Virol. 64, 171-173.

Hrabar, A. I., Vodopija, I., Andre, F. E., Mitchell, J. R., MaAssab, H. F., HenNessy, V., and DAVENPORT, F. M. (1977). A placebo-controlled dose-response study of the reactogenicity and immunogenicity of a cold-adapted recombinant AVictoria/3/75 ( $\mathrm{H} 3 \mathrm{~N} 2)$ live influenza virus candidate vaccine in healthy volunteers. Dev. Biol. Stand. 39, 53-60

HUDDLESTON, J., and BROWNLEE, G. G. (1982). The sequence of the nucleoprotein gene of human influenza $A$ virus, strain $A / N T / 60 / 68$. Nucleic Acids Res. 10, 1029-1038.

INGLIS, S. C., BARRETT, T., BROWN, C. M., and ALmOND, J. W. (1979). The smallest genome RNA segment of influenza virus contains two genes that may overlap. Proc. Natl. Acad. Sci. USA 76, 37903794.

Jones, K. L., Huddleston, J. A., and Brownlee, G. G. (1983). The sequence of RNA segment 1 of influenza virus A/NT/60/68 and its comparison with the corresponding segment of strains A/PR/8/34 and AWSN/33. Nucleic Acids Res. 11, 1555-1566.

KAPTEIN, J. S., and NAYAK, D. P. (1982). Complete nucleotide sequence of the polymerase 3 gene of human influenza virus AMSN/ 33. J. Virol. 42, 55-63.

Kendal, A. P., Maassab, H. F., Alexandrova, G. I., and Ghendon, $Y$.Z. (1981). Development of cold-adapted recombinant live, attenuated influenza A vaccines in the U.S.A. and U.S.S.R. Antiviral Res. 1, 339-365.

LAMB, R. A., and CHOPPIN, P. W. (1979). Segment 8 of the influenza virus genome is unique in coding for two polypeptides. Proc. Natl. Acad. Sci. USA 76, 4908-4912.

LAMB, R. A., CHOPPIN, P. W., CHANOCK, R. M., and LAl, C-J. (1980), Mapping of the two overlapping genes for polypeptides NS1 and NS2 on RNA segment 8 of the influenza virus genome. Proc. Natt. Acad. Sci. USA 77, 1857-1861.

LAMB, R. A., LAI, C-J., and CHOPPIN, P. W. (1981). Sequences of mRNAs derived from genome RNA segment 7 of influenza virus: Colinear and interrupted mRNAs code for overlapping proteins. Proc. Natl. Acad. Sci. USA 78, 4170-4174.

LA Montagne, J. R., Wright, P. F., Clements, M. L., MaAssab, H. F., and MURPHY, B. R. (1983). Prospects for live, attenuated influenza vaccines using reassortants derived from the A/Ann Arbor/6/60 (H2N2) cold-adapted (ca) donor virus. In "The Origin of Pandemic Influenza Viruses" (W. G. Laver, Ed.), pp. 243-257. Elsevier, New York.

LAZAR A., OKABE, N., and WRIGHT, P. F. (1980). Humoral and cellular immune responses of seronegative children vaccinated with a cold-adapted influenza $\mathrm{A} / \mathrm{HK} / 123 / 77$ (H1N1) recombinant virus. Infect. Immun. 27, 862-866.

MAASSAB, H. F. (1967). Adaption and growth characteristics of influenza virus at $25^{\circ} \mathrm{C}$. Nature (London) $213,612-614$.

Maasab H. F., Kendal A. P., Abrams G. D., and Monto A. S. (1982). Evaluation of cold-recombinant influenza virus vaccine in ferrets. J. Infect. Dis. 146, 780-790.

MaAssab, H. F., Kendal, A. P., and DavenPort, F. M. (1972). Hybrid formation of influenza virus at $25^{\circ} \mathrm{C}$. Proc. Soc. Exp. Biol. Med. 139, 768-773.

Maniatis, T., Fritsch, E. F., and Sambrook, J. (1982). "Molecular Cloning: A Laboratory Manual," pp. 189-196. Cold Spring Harbor Laboratory, Cold Spring Harbor, NY.

MAXAM, A. M., and GILBERT, W. (1980). Sequencing end-labeled DNA with base-specific chemical cleavages. In "Methods in Enzymology" (L. Grossman and K. Moldave, Eds.), Vol. 65, pp. 497-559. Academic Press, New York.

Moritz, A. J., Kunz, C., Hofman, H., LeiHL, E., Reeve, P., and MaAs SAB, H. F. (1980). Studies with a cold-recombinant ANictoria/3/75 (H3N2) virus II: Evaluation in adult volunteers. J. Infect. Dis. 142, $857-860$.

Murphy, B. R., Chanock, R. M., Clements, M. L., Anthony, W. C., Sear, A. J., Cisneros, L. A., Rennels, M. B., Miller, E. H., Black, R. E., Levine, M. M., BetTS, R. F., DOUglas, R. G., JR., MAASSAB, H. F., COX, N. J., and KENDAL, A. P. (1981). Evaluation of AVAlaska/ 6/77 (H3N2) cold-adapted recombinant viruses from A/Ann Arbor/ $6 / 60$ cold-adapted donor virus in adult seronegative volunteers. Infect. Immun. 32, 693-697.

Murphy, B. R., HOlley, H. P., JR., Berquist, E. J., LeVIne, M. M. SpRing, S. B., MAASSAB, H. F., Kendal, A. P., and ChanoCk, R. M. (1979). Cold-adapted variants of influenza $A$ virus: Evaluation in adult seronegative volunteers of A/Scotland/840/74 and AVictoria/3/75 cold-adapted recombinants derived from the coldadapted AVAnn Arbor/6/60 strain. Infect. Immun. 23, 235-259. 
Murphy, B. R., Nelson, D. L., Wright, P. F., Tierney, E. L., Phelan, M. A., and CHANOCK, R. M. (1982). Secretory and systemic immunological response in children infected with live attenuated influenza A virus vaccines. Infect. Immun. 36, 1102-1108.

Murphy, B. R., Rennels, M. B., Douglas, R. G., BetTS, R. F., JR., ChaNock, R. M., Kendal, A. P., MaAssab, H. F., Suwanagool, S., SOtman, S. B., Cisneros, L. A., ANthony, W. C., Nalin, D. R., and LeVINE, M. M. (1980). Evaluation of influenza A/Hong Kong/123/77 ( $\mathrm{H} 1 \mathrm{~N} 1)$ ts- $1 \mathrm{~A} 2$ and cold-adapted recombinant viruses in seronegative adult volunteers. Infect. Immun. 29, 348-355.

Murphy, B. R., Tolpin, M. D., Massicot, J. G., KIM, H. Y., ParrotT, R. H., and CHANOCK, R. M. (1980). Escape of a highly defective influenza $A$ virus mutant from its temperature sensitive phenotype by extragenic suppression and other types of mutation. Ann. N.Y. Acad. Sci. 354, 172-182.

NakAIMA, K., NakAima, S., and SugluRA, A. (1982). The possible origin of H3N2 influenza virus. Virology 120, 504-509.

OdaGirI, T., TOSAKA, A., ISHIDA, N., and MAASSAB, H. F. (1986). Biological characteristics of a cold-adapted influenza $A$ virus mutation residing on a polymerase gene. Arch. Virol. 88, 91-104.

PALESE, P., and SCHULMAN, J. C. (1976). Difference in RNA patterns of influenza A virus. J. Virol. 17, 876-884.

Reeve, P. G., Almond, J. W., Felsenreich, V., Piberman, M., and MAASSAB, H. F. (1980a). Studies with cold-recombinant A/Victoria/ $3 / 75$ (H3N2) virus. I. Biologic, genetic, and biochemical characterization. J. Infect. Dis. 142, 850-856.

Reeve, P. G., Batia, G., Moritz, A., Liehl, E., Kunz, C., Hofman, H., and MAASSAB, H. F. (1980b). Studies in man with cold-recombinant influenza virus ( $\mathrm{H} 1 \mathrm{~N} 1)$ live vaccines. J. Med. Virol. 6, 75-83.

ROBERTSON, J. S. (1979). $5^{\prime}$ and $3^{\prime}$ terminal nucleotide sequences of the RNA genome segments of influenza virus. Nucleic Acids Res. $6,3745-3757$.

Robertson, J., Robertson, M., and Roditi, I. (1984). Nucleotide sequence of RNA segment 3 of the avian influenza A/FPV/Rostock/ 34 and its comparison with the corresponding segment of human strains A/PR/8/34 and A/NT/60/68. Virus Res. 1, 73-79.

RoberTSON, J., SCHUBERT, M., and LAZZARINI, R. A. (1981). Polyadenylation sites for influenza virus mRNA. J. Virol. 38, 157-163.

RoDiti, I., and RoberTSON, J. (1984). Nucleotide sequence of the avian influenza virus A/Fowl Plague/Rostock/34 Segment 1 encoding the PB2 polypeptide. Virus Res. 1, 65-71.

SANGer, F., Nicklen, S., and Coulson, A. R. (1977). DNA sequencing with chain-terminating inhibitors. Proc. Natl. Acad. Sci. USA 74, 5463-5467.

SCHOLTISSEK, C. (1984). Temperature-sensitive (ts) mutants of an influenza $A$ virus for which genetic synergism is required to express the ts phenotypes. Virus Res. 1, 677-685.

SCHOLTISSEK, C., RHODE, W., and VON HOYNigen, V. (1978). On the origin of human influenza subtypes $\mathrm{H} 2 \mathrm{~N} 2$ and $\mathrm{H} 3 \mathrm{~N} 2$. Virology 87 , 13-20.
SIVASUBRAMANIAN, N., and NAYAK, D. P. (1982). Sequence analysis of the polymerase 1 gene and the secondary structure prediction of polymerase 1 protein of human influenza virus A/WSN/33. I. Virol. 44, 321-329.

SKEHEL, J. J., and HAY, A. J. (1978). Nucleotide sequences at the $5^{\prime}$ termini of influenza virus RNAs and their transcripts. Nucleic Acids Res. 5, 1207-1219.

Snyder, M. H., Betts, R. F., DeBorde, D., Tierney, E. L., Clements, M. L., Herrington, D., Sears, S. D., Dolin, R., MaAssab, H. F., and MURPHY, B. R. (1987). Four viral genes independently contribute to attenuation of live influenza A/Ann Arbor/6/60 (H2N2) coldadapted reassortant virus vaccines. J. Virol. 62, 488-495.

Snyder, M. H., Clements, M. L., DeBorde, D., MaAssab, H. F., and MURPHY, B. R. (1985). Attenuation of wild-type human influenza $A$ virus by acquisition of the PA polymerase and matrix protein genes of influenza A/Ann Arbor/6/60 cold-adapted donor virus. J. Clin. Microbiol. 22, 719-727.

Spring, S. B., MaAssab, H. F., Kendal, A. P., Murphy, B. R., and ChaNOCK, R. M. (1977). Cold-adapted variants of influenza A. II. Comparison of the genetic and biological properties of ts mutants and recombinants of the cold-adapted A/AA/6/60 strain. Arch. Virol. $55,233-246$.

STOECKLE, M. Y., SHAW, M. W., and CHOPPIN, P. W. (1987). Segmentspecific and common nucleotide sequences in the noncoding regions of influenza B virus genome RNAs. Proc. Natl. Acad. Sci. USA 84, 2703-2707.

StUART-HARRIS, C. (1980). The present status of live influenza virus vaccine. J. Infect. Dis. 142, 784-793.

TOlpin, M. D., Massicot, J. G., Mullinix, M .G., Kim, H. W., Parrott, M. D., CHANOCK, R. M., and MURPHY, R. B. (1981). Genetic factors associated with loss of the temperature-sensitive phenotype of the influenza A/Alaska/77-ts-1A2 recombinant in vivo. Virology 112, 505-517.

VAN VOORTHUIZEN, F., JeNS, D., and SAES, F. (1981). Characterization and clinical evaluation of live influenza $A$ vaccine prepared from a recombinant of the AUSSR/92/77 ( $\mathrm{H} 1 \mathrm{~N} 1)$ and cold-adapted $\mathrm{A}$ Ann Arbor/6/60 (H2N2) strains. Antiviral Res. 1, 107-122.

WINTER, G., and FIELDS, S. (1980). Cloning of influenza cDNA into M13: The sequence of the RNA segment encoding the A/PR/8/34 matrix protein. Nucleic Acids Res. 8, 1965-1974.

WINTER, G., and FIELDS, S. (1981). The structure of the gene encoding the nucleoprotein of human influenza virus $A / P R / 8 / 34$. Virology $114,423-428$.

WINTER, G., and FIELDS, S. (1982). Nucleotide sequence of human influenza AVPR/8/34 segment 2. Nucleic Acids Res. 10, 21352143.

Wright, P. F., Okabe, N., McKeE, K. I., MaAssab, H. F., and Karzon, D. T. (1982). Cold-adapted recombinant influenza $A$ virus vaccines in seronegative young children. J. Infect. Dis. 146, 71-79.

Zebedee, S. L., Richardson, C. D., and LAMB, R. A. (1985). Characterization of the influenza virus $\mathrm{M}_{2}$ integral membrane protein and expression at the infected-cell surface from cloned cDNA. J. Virol. 56, 502-511. 